\title{
Three new species of Spiniloculus (Cestoda: Tetraphyllidea) from Chiloscyllium punctatum (Elasmobranchii: Orectolobiformes) off Borneo with clarification of the identity of the type of the genus
}

\author{
Leah Desjardins and Janine N. Caira
}

Department of Ecology \& Evolutionary Biology, University of Connecticut, 75 N. Eagleville Rd., Storrs, Connecticut 06269-3043, USA

\begin{abstract}
The type species (Spiniloculus mavensis Southwell, 1925) of the previously monotypic tetraphyllidean genus Spiniloculus Southwell, 1925 is redescribed from the type material from Moreton Bay, Australia. As a consequence the identity of this species is definitively resolved. Three new species in the genus, all collected from Chiloscyllium punctatum Müller et Henle (brownbanded bambooshark), in Borneo, are described. Spiniloculus calhouni sp. n. conspicuously differs from all three of its congeners in its possession of post-poral testes. Spiniloculus fylerae sp. n. and Spiniloculus paigeae sp. n. differ from their two other congeners in that they are relatively small worms (4-6.5 and 2.2-5 mm in total length, respectively) with fewer than 30 proglottids. They can be distinguished from one another in that, while the vitelline follicles are interrupted at the level of its ovary in S. fylerae, this is not the case in S. paigeae. Furthermore, whereas the cirrus sac of the former species is pyriform, it is elongate-oval in the latter species. This brings the total number of species in the genus to four, and lends support to the suggestion that the original identity of the type host of S. mavensis as Mustelus sp. was in error. This work also extends the range of the genus to include the island of Borneo. A key to the species of Spiniloculus is provided. Morphological data generated here, using both light and scanning electron microscopy, support the suggested close affinities between Spiniloculus and Yorkeria Southwell, 1927, both of which parasitize bamboosharks.
\end{abstract}

Keywords: Cestoda, Tetraphyllidea, Spiniloculus, Chiloscyllium, bamboo sharks, new species, Borneo

The cestode Spiniloculus mavensis Southwell, 1925 has been treated on a number of occasions by a diversity of authors, perhaps in large part as a result of its unusual scolex morphology. This species was originally described by Southwell (1925) from specimens collected from a shark identified as "Mustelus sp.", which had been sent to him from Moreton Bay, Australia. In an addendum, Southwell (1930) expanded on his original description of $S$. mavensis based on five specimens collected from Chiloscyllium indicum in Ceylon (i.e., Sri Lanka). Subhapradha (1955) reported the species from Chiloscyllium griseum Müller et Henle taken off the Madras Coast of India. Baer and Euzet (1962) reiterated the fact that the species also parasitizes Chiloscyllium indicum (Gmelin). Williams (1964) further expanded on Southwell's concept of the species based on specimens taken from $\mathrm{He}$ miscyllium punctatum (=Chiloscyllium punctatum) from Heron Island, Australia. Most recently, Caira (1990) used scanning electron microscopy to clarify the nature of the bothridial loculi of specimens taken from Chiloscyllium punctatum near Mackay and Balgal, Australia. Thus, at present the concept of $S$. mavensis is based on specimens taken from "Mustelus sp." and three species of Chiloscyllium from Australia, India, and Sri Lanka.
Given the high degree of host specificity exhibited by the hooked tetraphyllideans in general (e.g., Caira and Jensen 2001), it seems likely that the current understanding of the morphology and host associations of S. mavensis is based on material of several species. Although the suggestion that Spiniloculus may include more than a single species was made decades ago by Williams (1964), the unknown whereabouts of the type material has inhibited progress towards resolving this issue. The situation has recently changed owing to the discovery of three of Southwell's four type slides of $S$. mavensis in a collection of Southwell's specimens left in the care of L. Euzet by Jean Baer following their revision of Southwell's material (Baer and Euzet 1962). Examination of these specimens allowed resolution of some of the ambiguities present in the original and subsequent treatments of $S$. mavensis which is herein redescribed. Furthermore, new collections from three species of Chiloscyllium from Malaysian and Indonesian Borneo provide insight into the host associations of Spiniloculus. Material from one of these host species yielded specimens that, following a more definitive circumscription of $S$. mavensis, can now be recognized as representing three new species of Spiniloculus, each of which is described below. As a consequence the genus is 
definitively no longer monotypic. The interesting pattern of host associations that has emerged from examination of this newly collected material is considered.

\section{MATERIALS AND METHODS}

Specimens of Chiloscyllium Müller et Henle were collected from a diversity of localities in Malaysian and Indonesian Borneo (i.e. Kalimantan) between May 2002 and July 2007. The sharks examined consisted of 27 specimens of $C$. punctatum (14 males ranging in size from 41.1 to $91.3 \mathrm{~cm}$ in total length [TL] and 13 females ranging in size from 68 to $84 \mathrm{~cm} \mathrm{TL}$ ), 22 specimens of $C$. indicum ( 8 males ranging in size from 41.1 to $58 \mathrm{~cm}$ in TL and 14 females ranging in size from 38.7 to $60 \mathrm{~cm}$ in TL), and 7 specimens of Chiloscyllium hasselti Bleeker ( 3 males ranging in size from 42 to $76 \mathrm{~cm}$ in TL and 4 females ranging in size from 42 to $69 \mathrm{~cm}$ in TL). In each case, the spiral intestine was removed and opened with a longitudinal incision. Tapeworms were fixed in $4 \%$ formalin buffered in seawater and subsequently transferred to $70 \%$ ethanol for storage. Whole mounts for light microscopy were prepared as follows. Specimens were hydrated in a graded ethanol series, stained with Delafield's haematoxylin, dehydrated in a graded ethanol series, cleared in methyl salicylate, and mounted in Canada balsam under coverslips on glass slides. Specimens prepared as serial sections were dehydrated in a graded ethanol series, lightly stained in fast green, cleared in xylene, and embedded in paraffin. Serial sections of proglottids of one species were cut at approximately $8 \mu \mathrm{m}$ intervals, stained in Gill's haematoxylin, counterstained in eosin, cleared in xylene, and mounted on glass slides under coverslips in Canada balsam according to conventional techniques.

Illustrations were drawn with the aid of a drawing tube. Hook measurements taken consisted of total length and greatest width of the medial and lateral hooks. Terminology for elements of the scolex and strobila follows Caira et al. $(1999,2001)$. Microthrix terminology follows Chervy (2009). Measurements were made using a SPOT digital camera equipped with SPOT software (version 4.5) attached to a Zeiss Axioskop 2 compound microscope. All measurements are given in micrometres unless otherwise stated. For each measurement, the range is followed in parentheses by the mean, standard deviation, number of worms measured, and number of measurements taken, if more than one measurement was made per worm.

Specimens were prepared for examination with scanning electron microscopy (SEM) as follows. They were hydrated in a graded ethanol series, transferred to distilled water, post-fixed in $1 \%$ osmium tetroxide overnight, dehydrated in a graded ethanol series, transferred to hexamethyldisilizane (HMDS) (Ted Pella Inc., Redding, California) for approximately $10 \mathrm{~min}$ and, after removal of the bulk of hexamethyldisilizane, allowed to air dry in a fume hood. Specimens were then mounted on aluminum stubs with carbon tape, and sputter coated with approximately $35 \mathrm{~nm}$ of gold-palladium. Scanning electron microscopy was performed using a LEO/Zeiss DSM982 Gemini field emission scanning electron microscope.

Museum abbreviations are as follows: BMNH, The Natural History Museum of London, London, England; IPCAS, Institute of Parasitology, Academy of Sciences of the Czech Republic, České Budějovice, Czech Republic; LRP, Lawrence R. Penner Parasitology Collection, Department of Ecology and Evolutionary Biology, University of Connecticut, Storrs, Connecticut,
USA; MZB, Museum Zoologicum Bogoriense, Zoological Division, Research Center for Biology, Indonesian Institute of Science, Cibinong, Indonesia; MZUM(P) Muzium Zoologi, Universiti Malaya, Kuala Lumpur, Malaysia; SBC, Sarawak Biodiversity Center, Kuching, Sarawak, Malaysia; and USNPC, U.S. National Parasite Collection, Beltsville, Maryland, USA. Inquiry at a diversity of public and private collections globally resulted in the location of three of Southwell's four type specimens of Spiniloculus mavensis in the personal collection of L. Euzet. These specimens have been deposited at the Natural History Museum of London (BMNH Nos. 2011.1.4.1-3).

\section{RESULTS}

Spiniloculus mavensis Southwell, $1925 \quad$ Figs. 1-5

Redescription (based on whole mounts of 1 specimen labelled type and 2 specimens labelled cotypes): Worms euapolytic, 11.6-34.2 mm (24 \pm 11 ; 3) long, greatest width $730-914(802 \pm 98 ; 3)$ at scolex; 37-57 $(46 \pm 10 ; 3)$ proglottids per worm. Scolex consisting of cephalic peduncle and 2 pairs of bothridia. Bothridia fused in back-to-back pairs; each bothridial pair borne on a pedicel; bothridia 499-659 (587 $\pm 49 ; 3 ; 7)$ long, 317-408 (375 $\pm 35 ; 2$; 5) wide, with 1 pre-hook loculus, 1 pair of uni-pronged hooks, and 1 post-hook loculus; post-hook loculus with transverse muscle bundles at midlevel. Pre-hook loculus) 198-334 (267 $\pm 42 ; 3 ; 8)$ long, 287-372 (345 \pm 39 ; $1 ; 4)$ wide. Post-hook loculus 281-355 (316 $\pm 23 ; 3 ; 8)$ long, 317-408 (375 $\pm 35 ; 2 ; 5)$ wide. Pedicels $253-376$ $(327 \pm 56 ; 2 ; 4)$ long, 245-294 (269 $\pm 35 ; 1 ; 2)$ wide. Cephalic peduncle $393(393 \pm 0 ; 1)$ long, $242(242 \pm 0 ; 1)$ wide, with 4 coiled muscle bundles extending from posterior margin of scolex proper to anterior margin of strobila, 2 muscle bundles extending through each pedicel to attach to proximal surface of each bothridium in a pair. Lateral and medial hooks yellow, hollow, C-shaped, of approximate equal curvature, inconspicuously dissimilar in size, oriented anteriorly, with prongs rather than bases adjacent to one another. Medial hook $79-83(82 \pm 2 ; 3 ; 6)$ long, 53-60 (56 $\pm 3 ; 3 ; 4)$ wide at base; prong maximum width 15-20 (18 $\pm 2 ; 3 ; 6)$. Lateral hook 84-87 (85 \pm 1 ; 3 ; 6) long, 52-64 $(59 \pm 5 ; 3 ; 6)$ wide at base, prong width at middle of length $17-18(17 \pm 1 ; 3 ; 7)$. Scolex surfaces not examined with SEM; minute spinitriches visible on surfaces of pedicels and cephalic peduncle with light microscopy.

Proglottids acraspedote. Immature proglottids wider than long, becoming longer than wide with maturity. Mature proglottids $3-8(5 \pm 2 ; 3)$ in number, $1,954-2,889$ $(2,353 \pm 483 ; 3)$ long, 480-702 (562 $\pm 122 ; 3)$ wide, length to width ratio $4-5: 1(4: 1 \pm 0.4 ; 3)$. Testes $122-150$ $(137 \pm 14 ; 3)$ in total number, $30-71(49 \pm 14 ; 3$; 9) long, 44-75 (56 $\pm 9 ; 3 ; 9)$ wide, 1 layer deep, in multiple irregular pre-poral columns; post-poral testes absent. Cirrus sac pyriform, 248-324 (281 \pm 39 ; 3) long, 156-196 $(178 \pm 21 ; 3)$ wide, containing coiled cirrus; cirrus cov- 


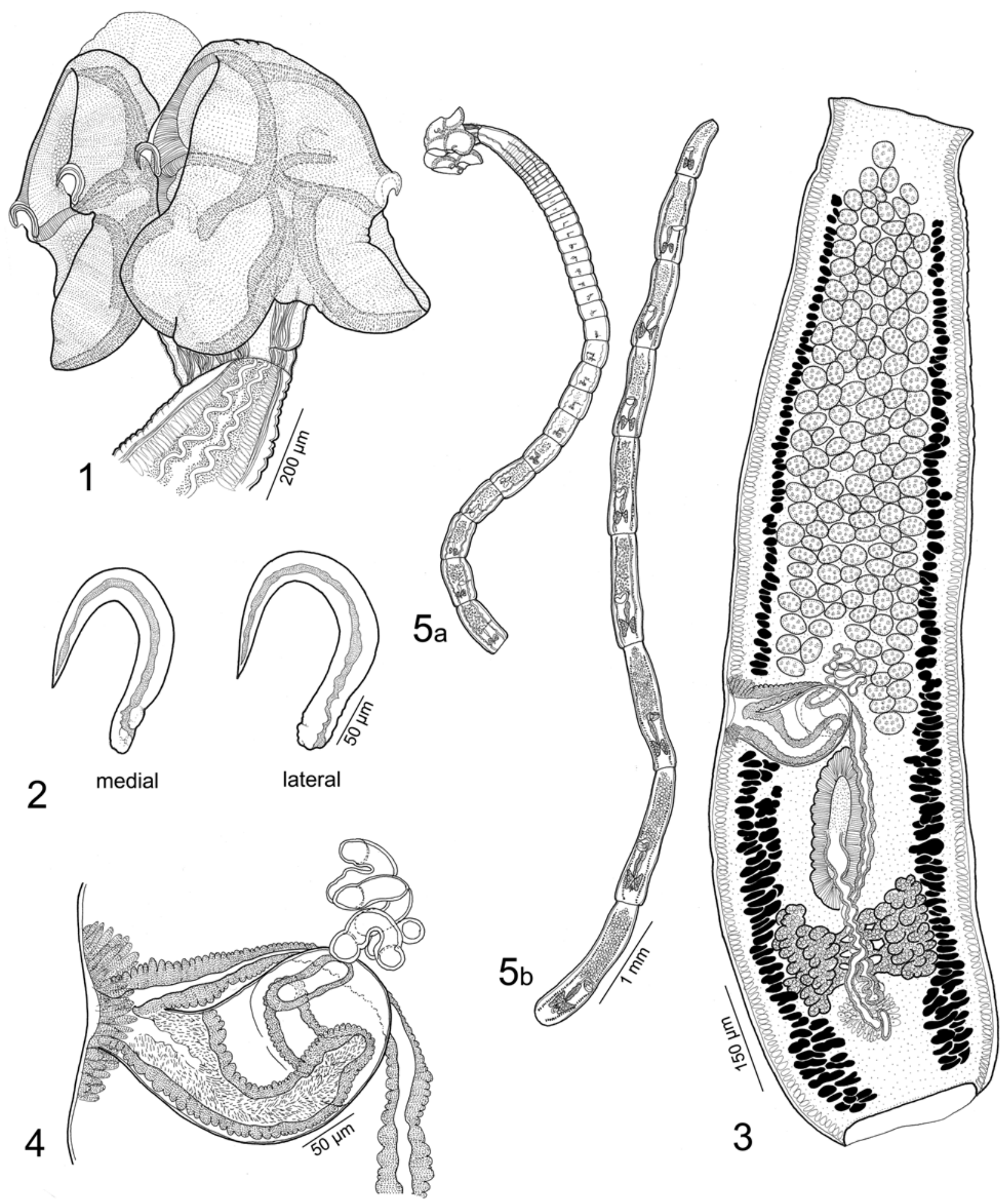

Figs. 1-5. Line drawings of Spiniloculus mavensis (BMNH No. 2011.1.4.1-3). Fig. 1. Scolex. Fig. 2. Hooks. Fig. 3. Terminal proglottid. Fig. 4. Detail of terminal genitalia. Fig. 5a, b. Whole worm.

ered with small spinitriches. Vas deferens minimal, arranged in relatively few small coils at anteromedial margin of cirrus sac, entering cirrus sac at anterior margin. Internal and external seminal vesicles lacking.
Ovary in posterior third of proglottid, 236-308 $(272 \pm 50 ; 2)$ long, 279-302 (291 $\pm 16 ; 2)$ wide, H-shaped in frontal view, tetralobed in cross-section, ovarian margins lobulated. Genital pores lateral, irregularly alternat- 
ing along length of strobila, $42-48 \%(45 \pm 4 ; 2)$ from posterior margin of proglottid. Vagina weakly sinuous, extending anteriorly from ootype region along midline of proglottid, then laterally along anterior margin of cirrus sac, opening into common genital atrium. Vitelline follicles in 2 lateral bands; each band consisting of 1 dorsal and 1 ventral column anterior to genital pore, and 2-3 columns of follicles posterior to genital pore; columns extending from approximately 3 rd row of testes to posterior margin of proglottid, interrupted on poral side by vagina and cirrus sac, uninterrupted by ovary. Mehlis' gland posterior to ovarian isthmus. Uterus extending from ootype to cirrus sac, ventral to vagina. Gravid proglottids not seen.

Type host of record: “'Ground-shark' (Mustelus sp.)”. Likely actual type host: Chiloscyllium cf. punctatum (Müller et Henle), brownbanded bambooshark.

Type locality: Moreton Bay, Brisbane, Queensland, Australia.

Additional locality: Balgal Beach, Queensland, Australia.

Site of infection: Spiral intestine.

Specimens deposited: Type and 2 cotypes: BMNH 2011.1.4.1-3.

E t y m o log y: Not given by Southwell (1925).

Remarks. The material examined here consists of a slide labelled "type", which bears the proglottid and hooks, and possibly also the scolex, figured by Southwell (1925) in the original description of $S$. mavensis, and two slides labelled "cotype". As a consequence, several of the inconsistencies surrounding the identity of $S$. mavensis, noted by Williams (1964), can now be resolved. This species should be considered to possess $122-150$ testes. Southwell's (1925; fig. 244) illustration of the proglottid should be considered to be schematic only because examination of the actual specimen reveals that particular proglottid actually bears 139 testes, rather than the 100 testes figured. Southwell's (1930) report of 180 testes in his material from $C$. indicum suggests he may have been dealing with a different species of Spiniloculus. In addition, while Southwell (1925) did not mention the presence of minute spines (=spinitriches sensu Chervy 2009) on the scolex of $S$. mavensis, they are clearly visible with a light microscope on the pedicels and cephalic peduncles of all three type specimens. In addition, it appears that Southwell's illustration of the terminal genitalia of the proglottid includes the cirrus, but not the cirrus sac. For clarification, a detail of the terminal genitalia has been provided here (Fig. 4). We have also presented a drawing of the complete type specimen (Fig. 5a, b) so as to allow $S$. mavensis to be more readily compared to its congeners.

We have restricted our redescription of $S$. mavensis to observations made on the type material taken from Moreton Bay, Australia. The Australian specimens identified as $S$. mavensis by both Williams (1964) and Caira (1990) have been intentionally excluded because both authors were working from a very small number of specimens and, given that Australia may also be found to be home to more than a single species of Spiniloculus, we believe this material is more appropriately considered in the context of a broader study focused specifically on the Australian member(s) of this genus.

\section{Spiniloculus calhouni sp. n.}

Figs. 6-16

Description (based on whole mounts of 6 complete worms and 2 scolices prepared for SEM): Worms euapolytic, $11.1-18.8 \mathrm{~mm}(14.1 \pm 2.7 ; 6)$ long, greatest width $760-1,803(1,156 \pm 396 ; 5)$ at scolex; 71-106 (88 \pm 12 ; $6)$ proglottids per worm. Scolex consisting of cephalic peduncle and 2 pairs of bothridia. Bothridia fused in back-toback pairs; each bothridial pair borne on a pedicel; bothridia $627-803(701 \pm 52 ; 5 ; 13)$ long, 312-506 (424 \pm 77 ; $4 ; 10)$ wide, with 1 pre-hook loculus, 1 pair of uni-pronged hooks, and 1 post-hook loculus; post-hook loculus with transverse muscle bundles at midlevel. Pre-hook loculus 230-329 (273 $\pm 36 ; 5 ; 14)$ long, 323-482 (398 $\pm 51 ; 4$; 11) wide. Post-hook loculus $365-475(427 \pm 36 ; 5 ; 12)$ long, 326-506 (433 $\pm 68 ; 4 ; 9)$ wide. Pedicels 196-480 $(306 \pm 105 ; 5 ; 9)$ long, 99-212 (150 $\pm 43 ; 5 ; 8)$ wide. Cephalic peduncle $237-421(335 \pm 81 ; 5)$ long, $140-300$ $(208 \pm 59 ; 5)$ wide, with 4 coiled muscle bundles extending from posterior margin of scolex proper to anterior margin of strobila, 2 muscle bundles extending through each pedicel to attach to proximal surface of each bothridium in a pair. Lateral and medial hooks yellow, hollow, C-shaped, of approximate equal curvature, inconspicuously dissimilar in size, oriented anteriorly, with prongs rather than bases adjacent to one another. Medial hook 95-129 (115 $\pm 11 ; 6 ; 19)$ long, 73-99 $(88 \pm 9 ; 5 ; 12)$ wide at base; prong maximum width $24-30(27 \pm 2 ; 5 ; 15)$. Lateral hook 95-130 (115 $\pm 10 ; 6 ; 16)$ long, 78-98 (91 \pm 7 ; $5 ; 9)$ wide at base, prong width at middle of length 18-30 $(25 \pm 3 ; 6 ; 15)$.

Distal surfaces of pre-hook loculus with papilliform filitriches (Fig. 12). Distal surfaces of post-hook loculus with lingulate spinitriches interspersed with papilliform filitriches (Fig. 13). Proximal bothridial surfaces with gladiate spinitriches interspersed with papilliform filitriches (Fig. 14). Surfaces of pedicels (Fig. 15) and cephalic peduncle (Fig. 16) with gladiate, slightly aristate spinitriches interspersed with acicular filitriches.

Proglottids acraspedote. Immature proglottids wider than long, becoming longer than wide with maturity. Mature proglottids $5-10(6 \pm 3 ; 6)$ in number, 588-1,145 $(923 \pm 187 ; 6)$ long, 478-748 (623 $\pm 111 ; 6)$ wide, length to width ratio $1-2: 1(2: 1 \pm 0.4 ; 6)$. Testes $127-177$ $(146 \pm 19 ; 6)$ in number, $14-37(28 \pm 6 ; 6 ; 18)$ long, $24-62$ $(45 \pm 12 ; 6 ; 18)$ wide, in multiple irregular pre-poral and post-poral columns; post-poral testes $10-20(15 \pm 2 ; 10$; 20 ) in number. Cirrus sac elongate-oval, slightly bent up, 276-345 (312 $\pm 29 ; 4)$ long, 61-108 (83 $\pm 21 ; 5)$ wide, 


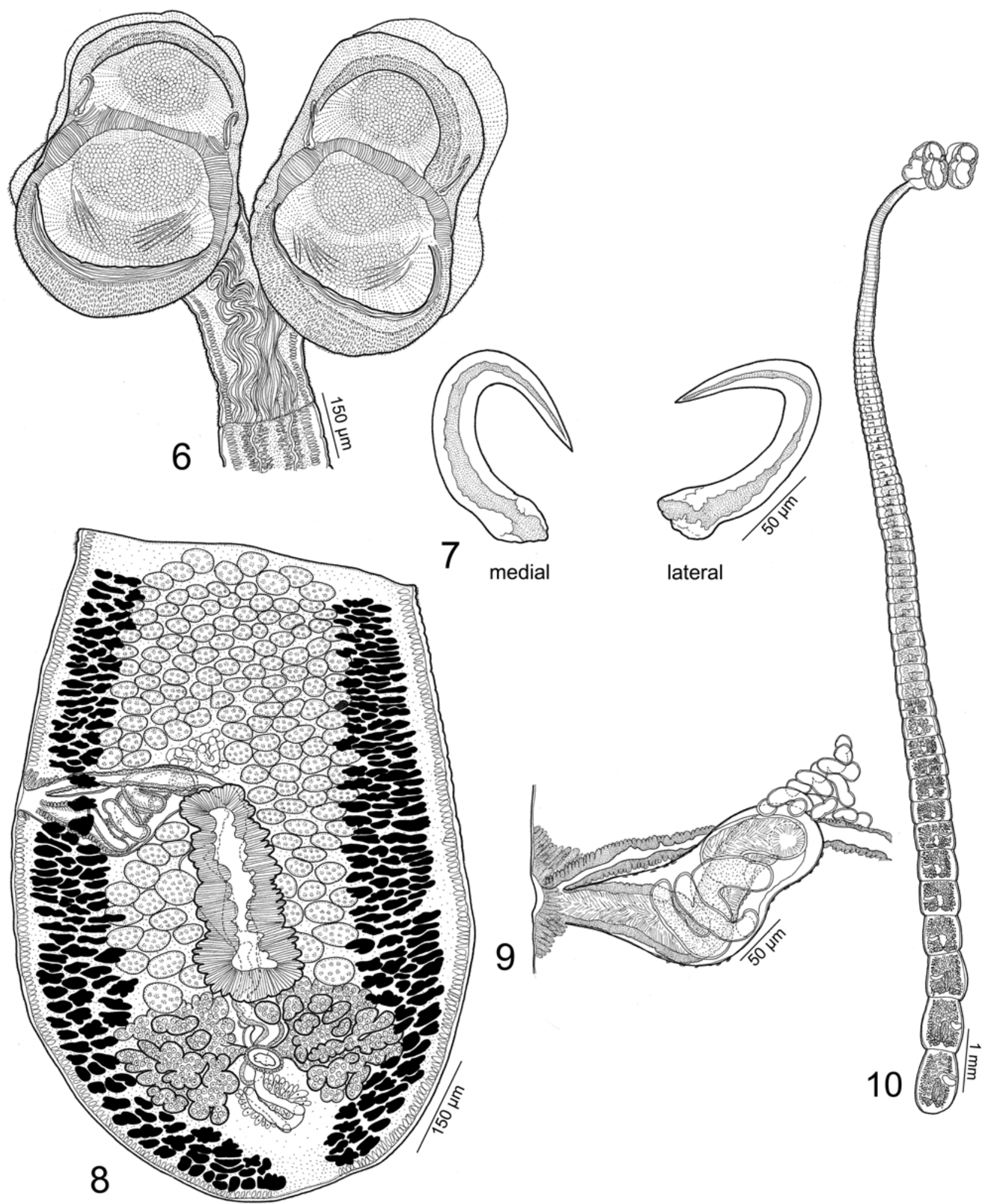

Figs. 6-10. Line drawings of Spiniloculus calhouni sp. n. Fig. 6. Scolex (MZUM[P] No. 2010.46(H)). Fig. 7. Hooks (LRP No. 7567). Fig. 8. Terminal proglottid (USNPC No. 104132). Fig. 9. Detail of terminal genitalia (USNPC No. 104132). Fig. 10. Whole worm (LRP No. 7567). 

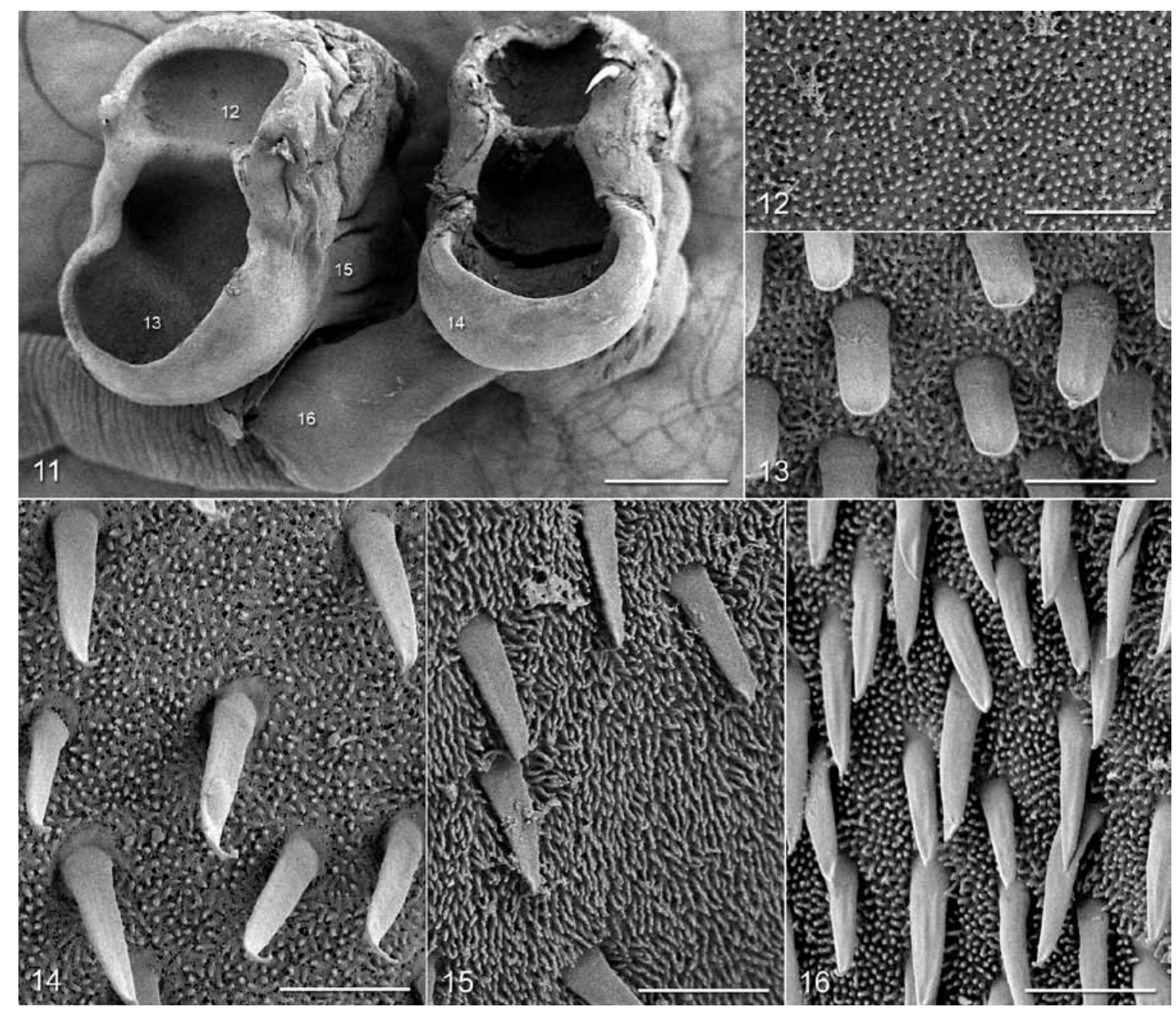

Figs. 11-16. Scanning electron micrographs of Spiniloculus calhouni sp. n. Fig. 11. Scolex. Note: small numbers correspond to the figures showing higher magnification images of these surfaces. Fig. 12. Distal surface of pre-hook bothridial loculus. Fig. 13. Distal surface of post-hook bothridial loculus. Fig. 14. Proximal surface of bothridium. Fig. 15. Surface of pedicel. Fig. 16. Surface of cephalic peduncle. Scale bars: Fig. $11=200 \mu \mathrm{m}$; Figs. $12-16=2 \mu \mathrm{m}$.

containing coiled cirrus; cirrus covered with small spinitriches. Vas deferens minimal, arranged in relatively few small coils at anteromedial margin of cirrus sac, entering cirrus sac at anteromedial margin. Internal and external seminal vesicles lacking.

Ovary in posterior third of proglottid, 105-194 (155 $\pm 34 ; 6)$ long, 223-453 (349 \pm 91 ; 6) wide, H-shaped in frontal view, tetralobed in cross-section, ovarian margins lobulated. Genital pores lateral, irregularly alternating along length of strobila, 53-61\% $(57 \pm 3 ; 6)$ from posterior margin of proglottid. Vagina sinuous, extending anteriorly from ootype region along midline of proglottid, then laterally along anterior margin of cirrus sac, opening into common genital atrium. Vitelline follicles in 2 lateral bands, each band consisting of multiple follicles; bands extending from approximately 3rd row of testes to posterior margin of proglottid, interrupted on poral side by vagina and dorsally by cirrus sac, uninterrupted by ovary. Mehlis' gland posterior to ovarian isthmus. Uterus ex- tending from ovarian isthmus to anterior margin of cirrus sac, ventral to vagina. Gravid proglottids not seen.

Type and only host: Chiloscyllium punctatum Müller et Henle, brownbanded bambooshark.

Type 1 ocality: Off Mukah, Sarawak, Malaysia $\left(2^{\circ} 54^{\prime} 0^{\prime \prime} \mathrm{N}\right.$, $\left.112^{\circ} 5^{\prime} 59^{\prime \prime} \mathrm{E}\right)$.

Site of infection: Spiral intestine.

Pr e v a l e n c e : 2 of 27 (7\%) of sharks examined; neither shark infected with other Spiniloculus or Yorkeria species.

Specimens deposited: Holotype (MZUM[P] No. 2010.46(H)), 1 paratype (IPCAS No. C-592), 1 paratype (LRP No. 7567), 2 SEM vouchers (LRP Nos. 7568-7569), 1 paratype (SBC No. P-00042), 2 paratypes (USNPC No. 104132).

Ety mology: This distinctive worm is named in honour of coach Jim Calhoun in recognition of his unwavering dedication to excellence, remarkable ability to recognize and culture talent, and for his contributions towards transforming the University of Connecticut into an institution of distinction. 

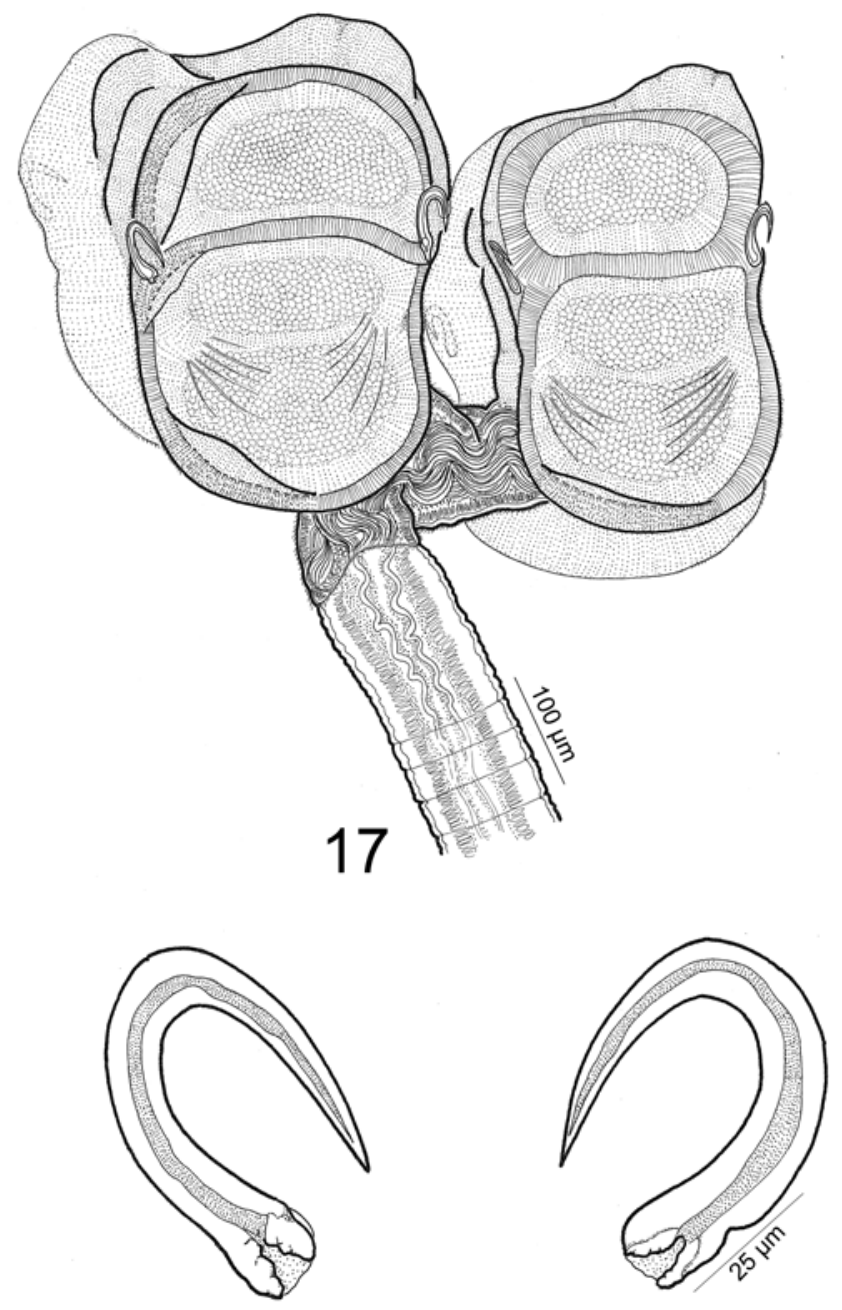

18 lateral
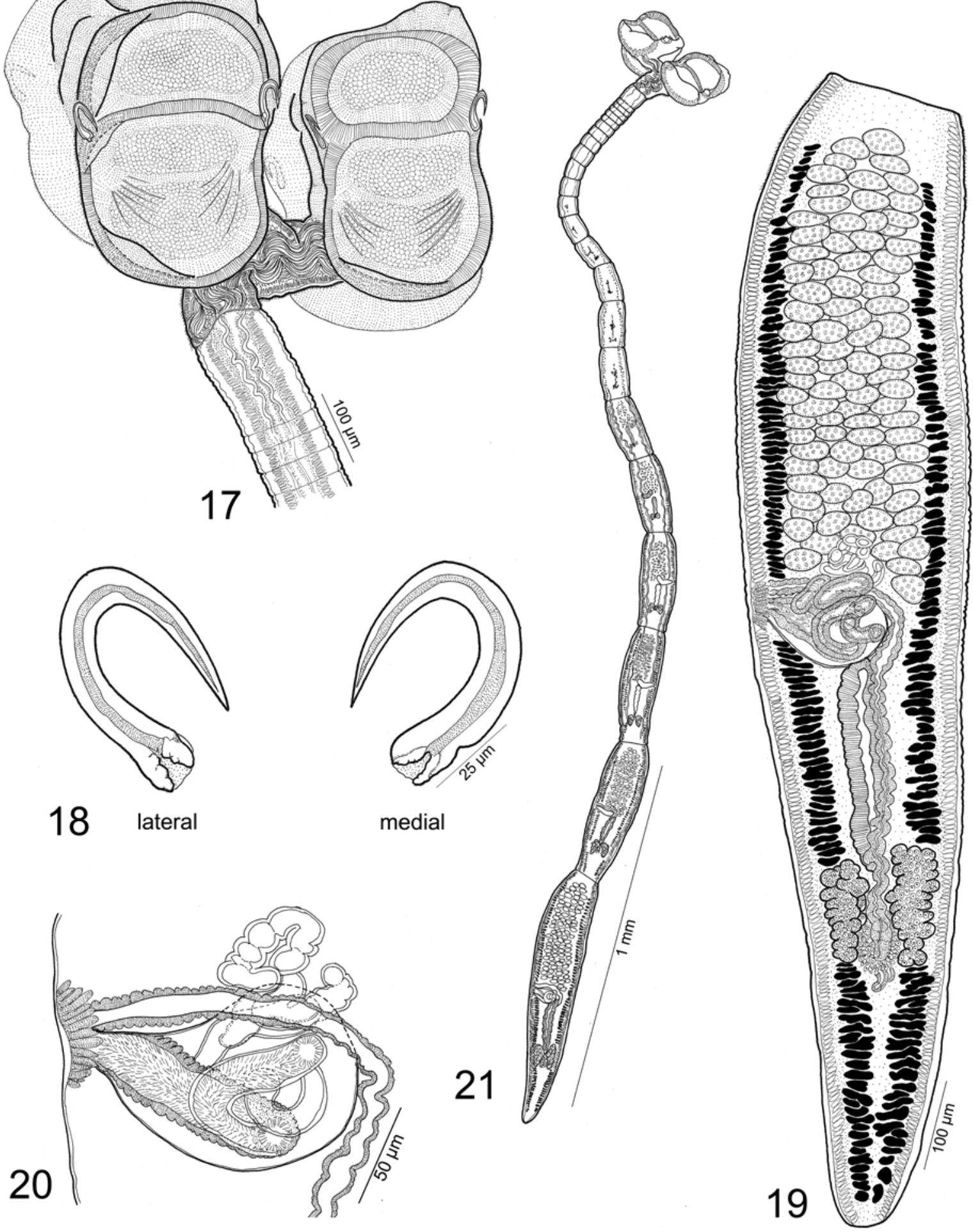

Figs. 17-21. Line drawings of Spiniloculus fylerae sp. n. Fig. 17. Scolex (MZUM[P] No. 2010.47(H)). Fig. 18. Hooks (LRP No. 7570). Fig. 19. Terminal proglottid (USNPC No. 104134). Fig. 20. Detail of terminal genitalia (USNPC No. 104134). Fig. 21. Whole worm (USNPC No. 104134). 


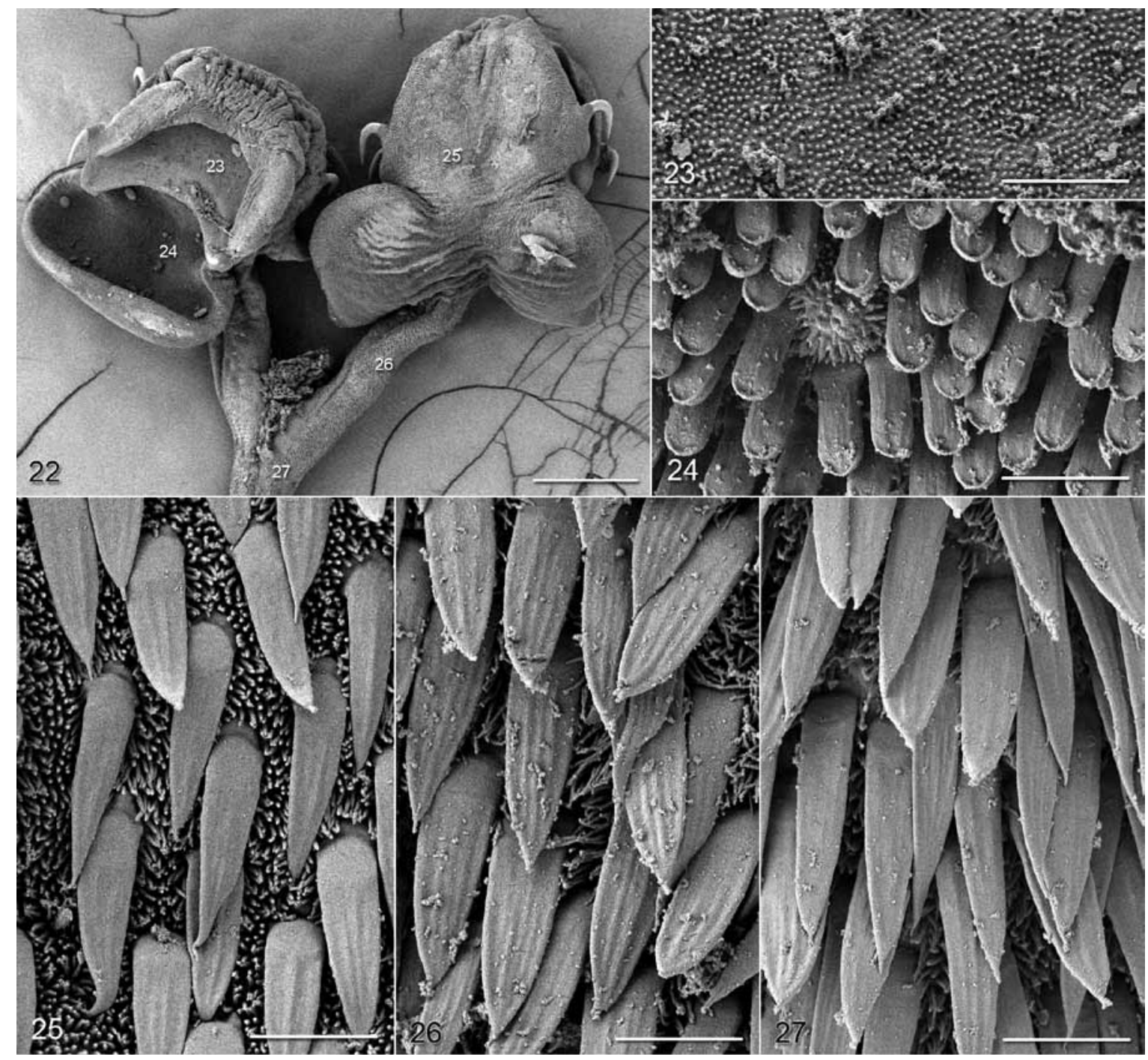

Figs. 22-27. Scanning electron micrographs of Spiniloculus fylerae sp. n. Fig. 22. Scolex. Note: small numbers correspond to the figures showing higher magnification images of these surfaces. Fig. 23. Distal surface of pre-hook bothridial loculus. Fig. 24. Distal surface of post-hook bothridial loculus. Fig. 25. Proximal surface of bothridium. Fig. 26. Surface of pedicel. Fig. 27. Surface of cephalic peduncle. Scale bars: Fig. $22=100 \mu \mathrm{m}$; Figs. $23-27=2 \mu \mathrm{m}$.

Remarks. This species conspicuously differs from S. mavensis in its possession of post-poral testes. It further differs from $S$. mavensis in its possession of a greater number of proglottids (71-106 vs. 37-57) and multiple vitelline follicles per lateral band, rather than $1-2$ columns of follicles in each band.

\section{Spiniloculus fylerae sp. n.}

Figs. $17-27$

Description (based on whole mounts of 10 complete worms, and 1 specimen prepared for SEM): Worms euapolytic, 4-6.5 mm $(5.2 \pm 1 ; 10)$ long, greatest width $559-782(674 \pm 71 ; 8)$ at scolex; $17-23(20 \pm 2 ; 10)$ proglottids per worm. Scolex consisting of cephalic peduncle and 2 pairs of bothridial. Bothridia fused in back-to-back pairs; each bothridial pair borne on a pedicel; bothridia
225-421 (341 $\pm 54 ; 10 ; 23)$ long, 204-333 (270 $\pm 34 ; 9$; 29 ) wide, with 1 pre-hook loculus, 1 pair of uni-pronged hooks, and 1 post-hook loculus; post-hook loculus with transverse muscle bundles at midlevel. Pre-hook loculus

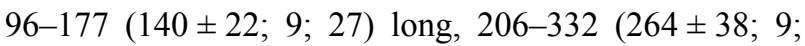
27) wide. Post-hook loculus $149-261(201 \pm 35 ; 8 ; 22)$ long, 204-333 (275 $\pm 32 ; 9 ; 31)$ wide. Pedicels 90-207 $(134 \pm 34 ; 6$; 12) long, 66-129 $(99 \pm 16 ; 6$; 11) wide. Cephalic peduncle 218-337 (273 $\pm 46 ; 5)$ long, 66-119 $(103 \pm 17 ; 7)$ wide, with 4 coiled muscle bundles extending from posterior margin of scolex proper to anterior margin of strobila, 2 muscle bundles extending through each pedicel to attach to proximal surface of each bothridium in a pair. Lateral and medial hooks yellow, hollow, C-shaped, of approximate equal curvature and size, oriented anteriorly, with prongs rather than bases adjacent 

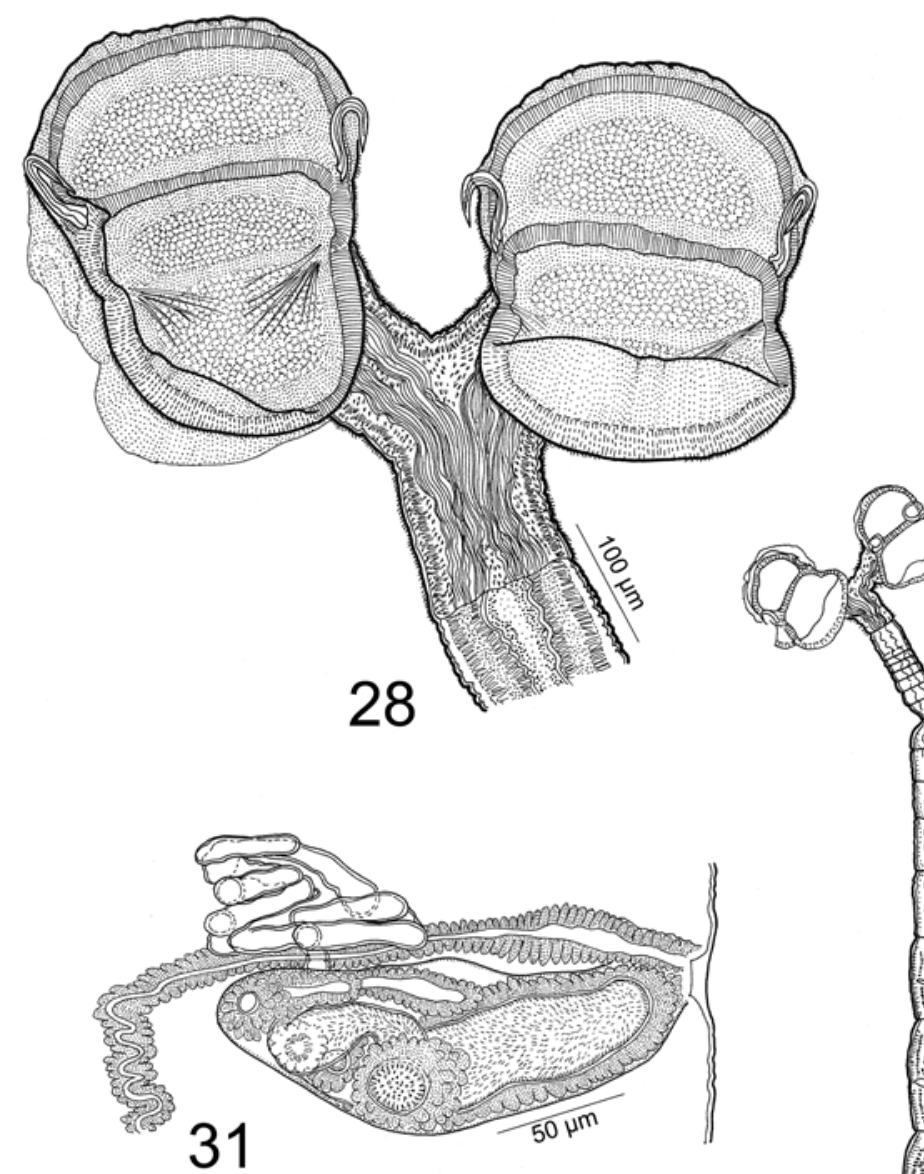

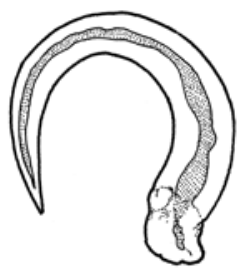

29 medial

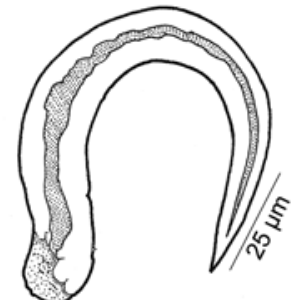

lateral

Figs. 28-32. Line drawings of Spiniloculus paigeae sp. n. Fig. 28. Scolex (USNPC No. 104129). Fig. 29. Hooks (MZUM[P] No. 2010.41(H)). Fig. 30. Terminal proglottid (MZUM[P] No. 2010.41(H)). Fig. 31. Detail of terminal genitalia (MZUM[P] No. 2010.41(H)). Fig. 32. Whole worm (MZUM[P] No. 2010.41(H)).

to one another. Medial hook $54-70(63 \pm 5 ; 9 ; 18)$ long, $31-50(45 \pm 6 ; 7 ; 11)$ wide at base; prong width at middle of length $11-16(13 \pm 2 ; 9 ; 17)$. Lateral hook $62-76$ $(69 \pm 4 ; 8 ; 14)$ long, $41-54(48 \pm 4 ; 8 ; 14)$ wide at base, prong maximum width $12-16(14 \pm 1 ; 8 ; 21)$.

Distal surfaces of pre-hook loculus with papilliform filitriches (Fig. 23). Distal surfaces of post-hook loculus with lingulate spinitriches interspersed with acicular filitriches (Fig. 24). Proximal bothridial surfaces with weakly aristate gladiate spinitriches interspersed with acicular filitriches (Fig. 25). Surfaces of pedicels (Fig. 26) and cephalic peduncle (Fig. 27) with weakly aristate gladiate spinitriches interspersed with capilliform filitriches.

Proglottids acraspedote. Immature proglottids wider than long, becoming longer than wide with maturity. Mature proglottids $1-2(1.1 \pm 0.4 ; 12)$ in number, $765-1,011$ (871 \pm 102 ; 9) long, 230-291 (275 \pm 17 ; 9) wide, length to width ratio $2-4: 1(3: 1 \pm 0.7 ; 9)$. Testes $87-102(94 \pm 6$; 7) in number, 13-28 (19 $\pm 4 ; 7$; 24) long, 22-53 (39 \pm 7 ; 7 ; 24) wide, in multiple irregular pre-poral columns; post-poral testes absent. Cirrus sac pyriform, 111-163 (142 $\pm 15 ; 8)$ long, 33-48 (41 $\pm 6 ; 8)$ wide, containing 
coiled cirrus; cirrus covered with small spinitriches. Vas deferens minimal, arranged in relatively few small coils at anteromedial margin of cirrus sac, entering cirrus sac near anteromedial margin. Internal and external seminal vesicles lacking.

Ovary in posterior third of proglottid, 75-120 $(100 \pm 16 ; 8)$ long, $106-150(135 \pm 17 ; 8)$ wide, H-shaped in frontal view, tetralobed in cross-section, ovarian margins lobulated. Genital pores lateral, irregularly alternating along length of strobila, 43-55\% $(50 \pm 4 ; 10)$ from posterior margin of proglottid. Vagina sinuous, extending anteriorly from ootype region along midline of proglottid, then laterally along anterior margin of cirrus sac, opening into common genital atrium. Vitelline follicles in 2 lateral bands; each band consisting of 1 dorsal and 1 ventral column of follicles, extending from approximately $3 \mathrm{rd}$ row of testes to posterior margin of proglottid, interrupted dorsally on poral side by vagina and cirrus sac, interrupted by ovary; Mehlis' gland posterior to ovarian isthmus. Uterus extending from ovarian isthmus to cirrus sac, ventral to vagina. Gravid proglottids not seen.

Type and only known host: Chiloscyllium punctatum (Müller et Henle), brownbanded bambooshark.

Type locality: Off Mukah, Sarawak, Malaysia $\left(2^{\circ} 54^{\prime} 0^{\prime \prime} \mathrm{N}\right.$, $\left.112^{\circ} 5^{\prime} 59^{\prime \prime} \mathrm{E}\right)$.

Additional locality: Off Kelapseban, Central Kalimantan, Indonesia $\left(3^{\circ} 14^{\prime} 29.6^{\prime \prime} \mathrm{S}, 112^{\circ} 54^{\prime} 52^{\prime \prime} \mathrm{E}\right)$.

Site of infection: Spiral intestine.

Prevalence: 5 of 27 (18.5\%) of sharks examined; 1 of 9 from Kelapseban; 4 of 18 from Mukah; 1 shark also with S. paigeae, 3 sharks also with S. paigeae and Yorkeria yubodoensis, and 1 shark also with S. paigeae, Yorkeria saliputium, and Yorkeria yubodoensis.

Specimens deposited: Holotype (MZUM[P] No. 2010.47(H)), 1 paratype (MZUM[P] No. 2010.48(P)), 1 paratype (IPCAS No. C-593), 2 paratypes (LRP Nos. 7570-7571), 1 SEM voucher (LRP 7572), 1 paratype (MZB No. Ca 141), 1 paratype (SBC No. P-00043), 3 paratypes (USNPC Nos. 104133-104134).

Ety mology: This species is named in honour of Dr. Carrie Fyler in recognition of her support and encouragement of the first author.

Remarks. This species conspicuously differs from $S$. calhouni in that it lacks post-poral testes. It is a substantially smaller worm than both $S$. calhouni and $S$. mavensis (4-6.5 mm TL vs. 11.1-18.8 and 11.6-34.2, respectively). It also possesses fewer testes than both species (87-102 vs. 127-177 and 122-150, respectively) and, unlike both species, exhibits vitelline follicles that are interrupted by the ovary.

\section{Spiniloculus paigeae sp. $\mathrm{n}$.}

Figs. 28-40

Description (based on whole mounts of 16 complete worms, cross-sections of 2 proglottids and 2 specimens prepared for SEM): Worms euapolytic, 2.5-5 mm
$(3.3 \pm 0.6 ; 16)$ long, greatest width 530-815 (660 \pm 86 ; $12)$ at scolex; $10-21(14 \pm 3 ; 16)$ proglottids per worm. Scolex consisting of cephalic peduncle and 2 pairs of bothridia. Bothridia fused in back-to-back pairs; each bothridial pair borne on a pedicel; bothridia 277-460 (365 $\pm 42 ; 17 ; 33)$ long, 230-370 (289 \pm 37 ; 17; 40) wide, with 1 pre-hook loculus, 1 pair of uni-pronged hooks, and 1 post-hook loculus; post-hook loculus with transverse muscle bundles at midlevel. Pre-hook loculus 97-198 $(152 \pm 21 ; 17 ; 39)$ long, 221-325 (264 $\pm 27 ; 17 ; 41)$ wide. Post-hook loculus $135-318(218 \pm 38 ; 17 ; 33)$ long, 195 $370(285 \pm 41 ; 17 ; 38)$ wide. Pedicels $172-240(204 \pm 29$; 5 ; 4) long, 60-125 $(89 \pm 16 ; 17$; 24) wide. Cephalic pe-

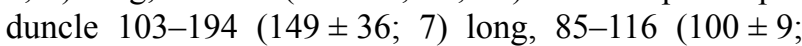
11) wide, with 4 coiled muscle bundles extending from posterior margin of scolex proper to anterior margin of strobila, 2 muscle bundles extending through each pedicel to attach to proximal surface of each bothridium in a pair.

Lateral and medial hooks yellow, hollow, C-shaped, of approximate equal curvature, lateral hook slightly larger than medial hook, oriented anteriorly, with prongs rather than bases adjacent to one another. Medial hook 52-72 $(63 \pm 5 ; 18 ; 33)$ long, $29-50(39 \pm 6 ; 18 ; 26)$ wide at base; prong width at middle of length $9-15(11 \pm 2 ; 18 ; 36)$. Lateral hook 61-84 (70 $\pm 5 ; 18 ; 38)$ long, 32-53 (46 \pm 6 ; $18 ; 24)$ wide at base, prong maximum width $8-17$ (12 \pm 2 ; $18 ; 36)$.

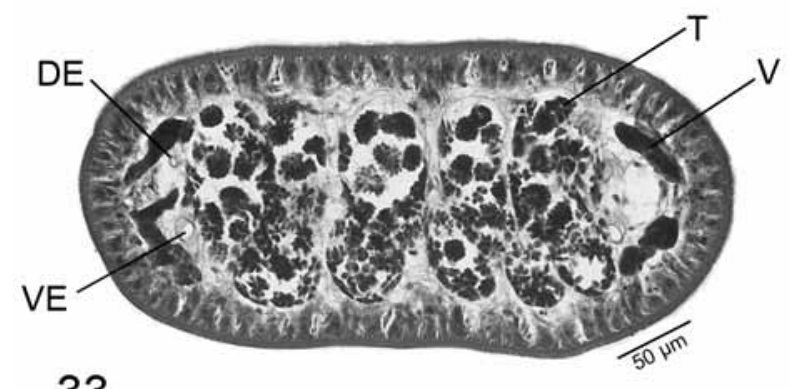

33

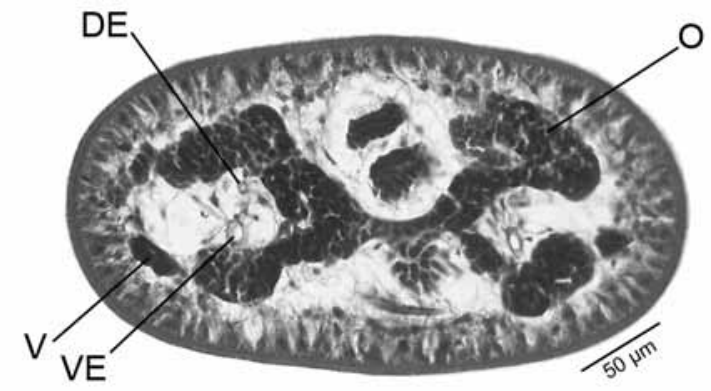

\section{4}

Figs. 33, 34. Cross-sections through mature proglottid of Spiniloculus paigeae sp. n. Fig. 33. Section through testes above terminal genitalia. Fig. 34. Section through ovary. Abbreviations: $\mathrm{DE}$ - dorsal excretory duct; $\mathrm{O}$ - ovary; $\mathrm{T}$ - testis; $\mathrm{V}$ - vitelline follicle; VE - ventral excretory duct. 

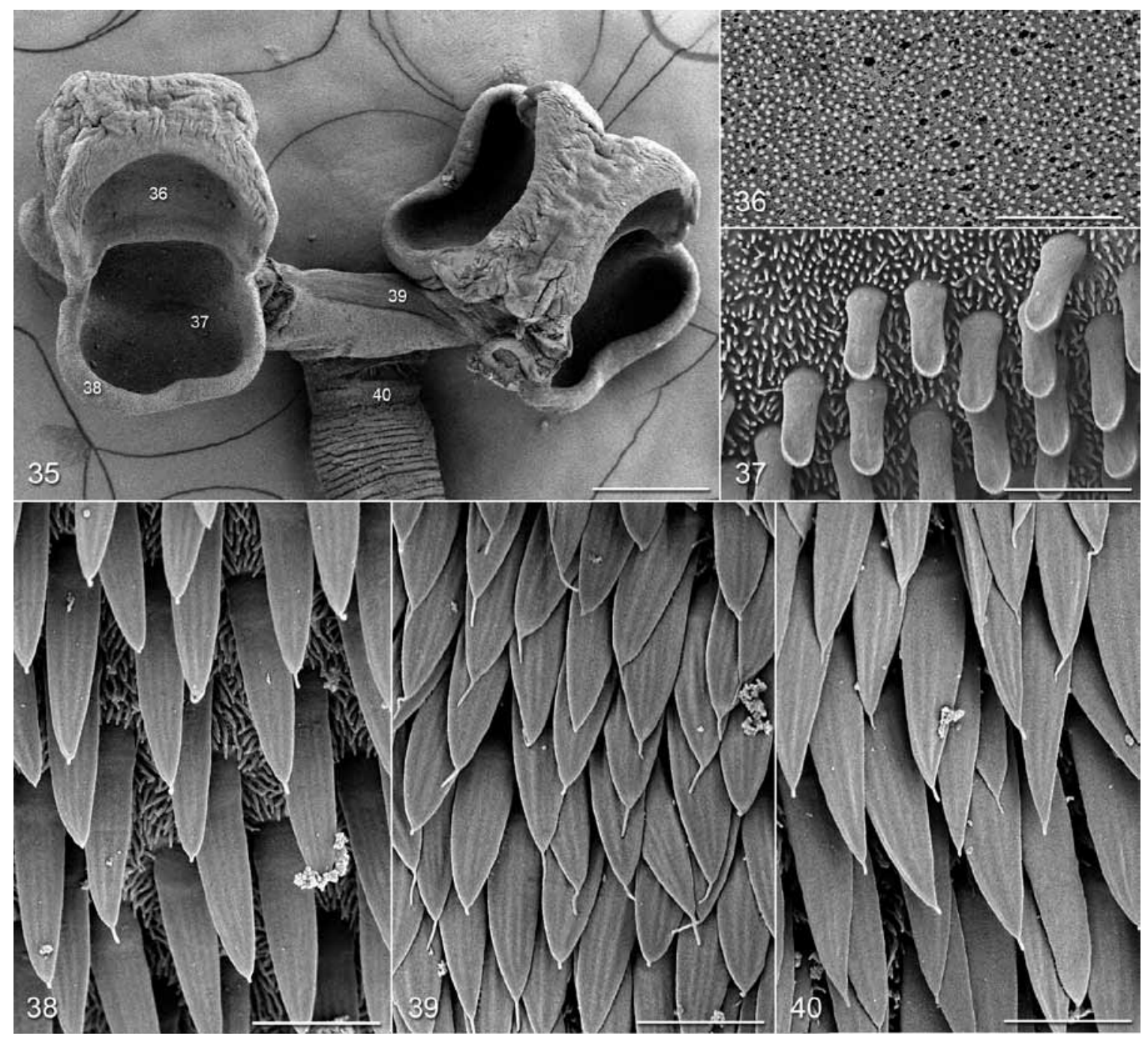

Figs. 35-40. Scanning electron micrographs of Spiniloculus paigeae sp. n. Fig. 35. Scolex. Note: small numbers correspond to the figures showing higher magnification images of these surfaces. Fig. 36. Distal surface of pre-hook bothridial loculus. Fig. 37. Distal surface of post-hook bothridial loculus. Fig. 38. Proximal surface of bothridium. Fig. 39. Surface of pedicel. Fig. 40. Surface of cephalic peduncle. Scale bars: Fig. $35=100 \mu \mathrm{m}$; Figs. $36-40=2 \mu \mathrm{m}$.

Distal surfaces of pre-hook loculus with papilliform filitriches (Fig. 36). Distal surfaces of post-hook loculus with lingulate spinitriches interspersed with acicular filitriches (Fig. 37). Proximal bothridial surfaces with aristate gladiate spinitriches interspersed with acicular filitriches (Fig. 38). Surfaces of pedicels (Fig. 39) and cephalic peduncle (Fig. 40) with aristate gladiate spinitriches interspersed with acicular filitriches.

Proglottids acraspedote. Immature proglottids wider than long, becoming longer than wide with maturity. Mature proglottids $1(\mathrm{n}=15)$ in number, $665-1,110$ (843 \pm 147 ; 15) long, 209-351 $(253 \pm 37$; 15) wide, length to width ratio $3-5: 1(3: 1 \pm 0.5 ; 14)$. Testes $74-98$ $(88 \pm 6 ; 12)$ in number, $10-23(16 \pm 3 ; 14 ; 36)$ long, $22-$ $50(35 \pm 7 ; 14 ; 36)$ wide, 1 layer deep (Fig. 33), arranged in multiple irregular pre-poral columns; post-poral testes absent. Cirrus sac elongate-oval, 120-193 $(153 \pm 26 ; 8)$ long, 30-52 $(38 \pm 7 ; 8)$ wide, containing coiled cirrus; cirrus covered with small spinitriches. Vas deferens minimal, arranged in relatively few small coils at anteromedial margin of cirrus sac, entering cirrus sac near anteromedial margin. Internal and external seminal vesicles lacking.

Ovary in posterior third of proglottid, 56-113 (82 \pm 19 ; 9) long, 53-170 (114 \pm 34 ; 9) wide, H-shaped in frontal view, tetralobed in cross-section (Fig. 34), ovarian margins lobulated. Genital pores lateral, irregularly alternating along length of strobila, $52-64 \%(56 \pm 3 ; 14)$ from posterior margin of proglottid. Vagina sinuous, extending anteriorly from ootype region along midline of proglottid, then laterally along anterior margin of cirrus sac, opening into common genital atrium. Vitelline follicles in 2 lateral bands; each band consisting of 1 dorsal and 1 ventral column, bands extending from approximately 3rd row of testes to posterior margin of proglottid, uninterrupted 
by vagina, cirrus sac or ovary; Mehlis' gland posterior to ovarian isthmus. Uterine duct entering uterus posterior to midlevel. Uterus extending from ovarian isthmus to anterior margin of cirrus sac, ventral to vagina. Gravid proglottids not seen.

Type and only known host: Chiloscyllium punctatum (Müller et Henle), brownbanded bambooshark.

Type locality: Off Mukah, Sarawak, Malaysia $\left(2^{\circ} 54^{\prime} 0^{\prime \prime} \mathrm{N}\right.$, $\left.112^{\circ} 5^{\prime} 59^{\prime \prime} \mathrm{E}\right)$.

Additional locality: Off Kelapseban, Central Kalimantan, Indonesia (3 $\left.3^{\circ} 4^{\prime} 29.6^{\prime \prime} \mathrm{S}, 112^{\circ} 54^{\prime} 52^{\prime \prime} \mathrm{E}\right)$.

Site of infection: Spiral intestine.

Prevalence: 7 of 27 (26\%) of sharks examined; 7 of 18 from Mukah; 1 of 9 from Kelapseban; 2 sharks with no other species of Spiniloculus or Yorkeria, 1 shark also with Yorkeria pusillulus, 4 sharks also with S. fylerae and Yorkeria yubodoensis, and 1 shark also with $S$. fylerae, $S$. saliputium, and Yorkeria yubodoensis.

Specimens deposited: Holotype (MZUM[P] No. 2010.41(H)), 4 paratypes (MZUM[P] Nos. 2010.42(P)2010.45(P)), 1 paratype (SBC No. P-00041), 5 paratypes (USNPC Nos. 104129-104130), cross-sections of 1 paratype and corresponding voucher (USNPC No. 104131), 1 paratype (IPCAS No. C-594), 4 paratypes (LRP Nos. 7556-7559), cross-sections of 1 paratype and corresponding voucher (LRP Nos. 7562-7566), 2 SEM vouchers (LRP Nos. 7560-7561).

Etymology: This species was named after Paige Desjardins, the younger sister of the first author.

Remarks. This species is readily distinguished from $S$. calhouni in that it lacks post-poral testes. It further differs from $S$. calhouni and differs from $S$. mavensis in that it is conspicuously shorter in total length $(2.5-5 \mathrm{~mm}$ vs. $11.1-18.8$ and 11.6-34.2, respectively). It also possesses fewer proglottids (10-21 vs. 71-106 and 37-57, respectively) and fewer testes (74-98 vs. 127-177 and 122-150, respectively) than both species. Spiniloculus paigeae most closely resembles $S$. fylerae, but differs in the form of its cirrus sac, which is elongate-oval in $S$. paigeae, but pyriform in S. fylerae. Furthermore, whereas the vitelline follicles are interrupted by the ovary in S. fylerae, this is not the case in $S$. paigeae.

\section{Other Chiloscyllium species examined}

In Borneo, species of Spiniloculus were found parasitizing only Chiloscyllium punctatum. The prevalences of each of the three new species of this genus in this host species are given above. No shark was found to host all three species of Spiniloculus. However, all five of the specimens of C. punctatum that hosted Spiniloculus fylerae also hosted S. paigeae. Both of the sharks infected with S. calhouni hosted no other species of Spiniloculus.

No specimens of Spiniloculus were found in any of the 22 specimens of Chiloscyllium indicum necropsied from any of the localities in Malaysian or Indonesian Borneo.
Similarly, none of the seven specimens of Chiloscyllium hasselti collected from Malaysian Borneo, was found to host any of the species of Spiniloculus.

\section{DISCUSSION}

This brings the total number of species of Spiniloculus to four and extends the range of the genus to include both Malaysian and Indonesian Borneo. In addition, this work provides some insight into the host associations of members of this genus. First, it lends support to Caira's (1990) suggestion that the identification of the original host of Spiniloculus mavensis may have been in error. Evidence includes: (1) The remarkably high host fidelity generally exhibited by the Onchobothriidae (see Caira and Jensen 2001), which calls into question reports of a genus parasitizing hosts belonging to two different orders. Whereas Southwell's (1925) report is from Mustelus (family Triakidae; order Carcharhiniformes), Southwell (1930), Subhapradha (1955), Baer and Euzet (1962), Williams (1964), and Caira (1990) all reported Spiniloculus from species of Chiloscyllium (family Hemiscylliidae; Orectolobiformes). (2) Despite work on a diversity of Mustelus species in or around the original locality of $S$. mavensis (e.g., Robinson 1959, Alexander 1963, Nasin et al. 1997, Pickering and Caira 2008), Spiniloculus has not since been reported from a species of Mustelus. (3) All three of the new species described here were also found to parasitize species of Chiloscyllium. As a consequence, we believe the genus should be considered to parasitize only Chiloscyllium.

As noted above, previous reports suggest that Spiniloculus mavensis parasitizes a diversity of species of Chiloscyllium; for example, Southwell (1930) reported it from Chiloscyllium indicum in Sri Lanka and Subhapradha (1955) reported it from Chiloscyllium griseum in India. Although our sample sizes were not particularly high, our failure to find Spiniloculus in C. indicum and C. hasselti in Borneo is interesting and bears further investigation. Also worth more detailed study would be specimens of Spiniloculus taken from C. indicum and C. griseum in Sri Lanka and India. For, given our results, we believe it likely that, assuming the original host identities of Southwell (1930) and Subhapradha (1955) were correct, both species of Chiloscyllium will be found to host species distinct from $S$. mavensis. Also of further interest would be the faunas of the following species of Chiloscyllium, which have not yet been examined for Spiniloculus: C. arabicum Gubanov, C. burmensis Dingerkus et DeFino, C. caeruleopunctatum Pellegrin and C. plagiosum Bennett.

At least nominally, all four described species of Spiniloculus have been reported from Chiloscyllium punctatum. While we are confident that the three species described here came from that host species, as noted by Caira et al. (2007), ongoing morphological and molecular work suggests that the bamboo shark species occurring in Australia, which has tentatively been identified as 
Chiloscyllium punctatum by some authors (e.g., Last and Stevens 2009), is not conspecific with the species in Borneo. Given the type locality of $C$. punctatum is Java, until such time as the taxonomy of this host genus has been addressed formally, the hosts of $S$. mavensis from Australia would more appropriately be referred to as Chiloscyllium cf. punctatum.

Spiniloculus now joins the ranks of the onchobothriid genera that include multiple species parasitizing the same host species such as, for example, Acanthobothrium (see Ghoshroy and Caira 2001, Fyler and Caira 2006, Fyler et al. 2009), Calliobothrium (see Nasin et al. 1997), and Pedibothrium (see Caira 1992, Caira et al. 2004). In fact, this is the second such onchobothriid genus reported from Chiloscyllium; Caira et al. (2007) reported two or more species of Yorkeria parasitizing three different species of Chiloscyllium. Given the close relationship between Yorkeria and Spiniloculus (see Caira et al. 1999, 2001) and the fact that a number of the host specimens examined by Caira et al. (2007) were among those examined here, it is interesting that, as reported in the taxonomic summaries above, several individual sharks were found to host both two species of Spiniloculus and two species of Yorkeria.

We concur with Euzet (1994) that Spinibiloculus Deshmukh et Shinde, 1980, with its type Spinibiloculus ratnagiriensis Deshmukh et Shinde, 1980, reported from Ginglymostoma concolor (Rüppell) (=Nebrius ferrugineus [Lesson]?) at Ratnagiri on the west coast of India, should be considered a junior synonym of Spiniloculus. We hereby formally transfer Spinibiloculus ratnagiriensis to this genus as Spiniloculus ratnagiriensis comb. n. As noted by Euzet (1994), essentially all of the features used by Deshmukh \& Shinde (1980) to distinguish Spinibiloculus from Spiniloculus do not appear to be valid. The bothridia, as illustrated, are not stalked, rather they are borne in back-to-back pairs on pedicels, as is the case in Spiniloculus. The post-hook loculus is undivided, a condition that has been discussed in a fair amount of detail (e.g., Williams 1964, Caira 1990), such that the post-hook loculus of Spiniloculus is now considered to lack an external costa. Most of the other articulated differences, such as testis number, must surely be considered of interspecific, rather than of intergeneric, importance. While the report that the vagina opens posterior to the cirrus sac is interesting, given that the vagina is invariably anterior to the cirrus sac in all other members of the order Tetraphyllidea, this observation requires confirmation. Overall, both the description and illustrations are superficial and thus, even with these irregularities aside, the validity of Spiniloculus ratnagiriensis remains to be confirmed. Unfortunately, Deshmukh and Shinde (1980) make no mention of the disposition of type material of their species. Furthermore, the identity of the type host of $S$. ratnagiriensis (i.e., Ginglymostoma concolor) is problematic. Not only is the published name a junior synonym of Nebrius ferrugineus Lesson, but examination of multiple specimens of Nebrius ferrugineus by several authors (e.g., Southwell 1925, Caira et al. 2004) has failed to yield a single specimen of Spiniloculus. This leads us to question the accuracy of the identification provided for the type host. In combination, all of these questions lead us to consider $S$. ratnagiriensis a species inquirenda until such time as it can be recollected, and/or the type specimens can be located and examined.

Finally, a comparison of the morphologies of Yorkeria Southwell, 1927 and Spiniloculus is in order. These genera share a number of unusual features that have led a diversity of authors to suggest they are closely related (e.g., Euzet 1994, Caira et al. 1999, 2001). For example, both bear C-shaped, yellow hooks that are oriented anteriorly. Both also bear four bothridia arranged in two back-toback pairs, each pair borne on a pedicel. In both genera the bothridia are composed of only two loculi, with the hooks located at the posterior margin of the first loculus. In both genera the uterus extends only to the midlevel of the proglottid. The SEM work conducted here shows that both genera also share lingulate spinitriches on the distal surfaces of their post-hook loculus. The close affinities of these two genera are interesting given that both groups have been confirmed to parasitize only species of Chiloscyllium (i.e., bamboo sharks).

However, the genera differ conspicuously in that, whereas the pre-hook loculus (i.e., the specialized anterior region of the bothridium) is inconspicuous and essentially apical in its orientation in Yorkeria, in Spiniloculus it is oriented parallel to the post-hook loculus, and thus comprises a major component of the face of the bothridium. Furthermore, whereas the hooks of Yorkeria are large relative to the size of the pre-hook loculus, extending throughout much of the area of the pre-hook loculus, in Spiniloculus the hooks are small, and often inconspicuous and are restricted to the lateral margins of this loculus. It is of note that among the 16 members of these two genera, $S$. calhouni is unique in its possession of post-poral testes.

\section{Key to species of Spiniloculus}

1 Post-poral testes present . . . Spiniloculus calhouni sp. n.

- Post-poral testes absent ........................................... 2

2 Worms $>10 \mathrm{~mm}$ in total length; with $>30$ proglottids per worm ............................. Spiniloculus mavensis

- Worms $\leq 10 \mathrm{~mm}$ in total length; with $\leq 30$ proglottids per worm 3

3 Cirrus sac pyriform; vitelline follicles interrupted by ovary ............................. Spiniloculus fylerae sp. n.

- Cirrus sac elongate-oval; vitelline follicles not interrupted by ovary ............. Spiniloculus paigeae sp. n. 
Acknowledgements. We are grateful to Kirsten Jensen for assisting with all aspects of the fieldwork conducted throughout Borneo, and to Gavin Naylor, Gordon Yearsley and Dharmadi for assisting with the collections of selected hosts. We are particularly grateful to Professor Louis Euzet for the role he played in locating the type material of Spiniloculus mavensis. We thank Patricia Pilitt, Margarita Naming, Susan Lim and Eileen Harris for assisting with the deposition of museum specimens. Collections in Sarawak were conducted under collecting permit
No. UPE:40/200/19SJ.924 from the Economic Planning unit in Kuala Lumpur and research agreement No. SBC-RA-0050-JNC from the Sarawak Biodiversity Center in Kuching. Collections in Kalimantan were conducted under collecting permits granted by LIPI. This work was supported in part with funds from NSF PEET grant DEB 0118882, NSF BS\&I grants DEB 0542846, DEB 0542941, and an REU supplement to that award, as well as NSF PB\&I grants DEB 0818696, and DEB 0818823.

\section{REFERENCES}

Alexander C.G. 1963: Tetraphyllidean and diphyllidean cestodes of New Zealand selachians. Trans. R. Soc. N. Z. 3: 117-142.

BAER J.G., Euzet L. 1962: Revision critique des cestodes Tétraphyllides décrit par T. Southwell. Bull. Soc. Neuchâtel. Sci. Nat. 71: 63-122.

CAIRA J.N. 1990: The tapeworm Spiniloculus mavensis (Tetraphyllidea: Onchobothriidae) from the brown banded bambooshark in Australia. Aust. J. Zool. 37: 705-710.

CAIRA J.N. 1992: Verification of multiple species of Pedibothrium in the Atlantic nurse shark with comments on the Australasian members of the genus. J. Parasitol. 78: 289-308.

Caira J.N., Jensen K. 2001: An investigation of the coevolutionary relationships between onchobothriid tapeworms and their elasmobranch hosts. Int. J. Parasitol. 31: 959-974.

Caira J.N., Jensen K., Healy C.J. 1999: On the phylogenetic relationships among tetraphyllidean, lecanicephalidean and diphyllidean tapeworm genera. Syst. Parasitol. 42: 77-151.

Caira J.N., Jensen K., Healy C.J. 2001: Interrelationships among tetraphyllidean and lecanicephalidean cestodes. In: D.T.J. Littlewood and R. Bray (Eds.). Interrelationships of the Platyhelminthes. Taylor and Francis, London and New York, pp. $135-158$.

Caira J.N., Jensen K., Rajan C. 2007: Seven new Yorkeria species (Cestoda: Tetraphyllidea) from Borneo and Australia and their implications for identification for Chiloscyllium (Elasmobranchii: Orectolobiformes) species. J. Parasitol. 93: 357-376.

Caira J.N., Tracy R., Euzet L. 2004: Five new species of Pedibothrium (Tetraphyllidea: Onchobothriidae) from the tawny nurse shark, Nebrius ferrugineus, in the Pacific Ocean. J. Parasitol. 90: 286-300.

Chervy L. 2009: Unified terminology for cestode microtriches: a proposal from the International Workshops on Cestode Systematics in 2002-2008. Folia Parasitol. 56: 199-230.

Deshmukn R.A., Shinde G.B. 1980: Spinibiloculus ratnagiriensis gen. n., sp. n. (Cestoda: Onchobothriidae) from a marine fish, Ginglymostoma concolor of the west coast of India. Acta Parasitol. Pol. 27: 431-435.
Euzet L. 1994: Order Tetraphyllidea Carus, 1863. In: L.F. Khalil, A. Jones and R.A. Bray (Eds.). Keys to the Cestode Parasites of Vertebrates. CAB International, Wallingford, UK, pp. 149-194.

Fyler C.A., CAira J.N. 2006: Five new species of Acanthobothrium (Cestoda: Tetraphyllidea) from the Freshwater Whipray (Himantura chaophraya). J. Parasitol. 92: 105-125.

Fyler C.A., Caira J.N., Jensen K. 2009: Five new species of Acanthobothrium (Cestoda: Tetraphyllidea) from an unusual species of Himantura (Rajiformes: Dasyatidae) from northern Australia. Folia Parasitol. 56: 107-128.

Ghoshroy S., Caira J.N. 2001: Four new species of Acanthobothrium (Cestoda: Tetraphyllidea) from the whiptail stingray Dasyatis brevis in the Gulf of California. J Parasitol. 87: 354-372.

Last P.R., Stevens J.D. 2009: Sharks and Rays of Australia. Harvard University Press, Cambridge, $644 \mathrm{pp}$

Nasin C.S., Caira J.N, Euzet L. 1997: Analysis of Calliobothrium (Tetraphyllidea: Onchobothriidae) with descriptions of three new species and erection of a new genus. J. Parasitol. 83: 714-733.

Pickering M., Caira J.N. 2008: Calliobothrium schneiderae sp. n. (Cestoda: Tetraphyllidea) from the spotted estuary smoothhound shark, Mustelus lenticulatus, from New Zealand. Comp. Parasitol. 75: 174-181.

Robinson E.S. 1959: Some new cestodes from New Zealand marine fishes. Trans. R. Soc. N. Z. 86: 381-392.

Southwell T. 1925: A monograph on the Tetraphyllidea with notes on related cestodes. Memoirs of the Liverpool School of Tropical Medicine (New Series) No. 2, 363 pp.

Southwell T. 1930: The Fauna of British India including Ceylon and Burma. Cestoda Vol II. Taylor and Francis, London, $262 \mathrm{pp}$.

Subhapradha C.K. 1955: Cestode parasites of fishes of Madras Coast. Indian J. Helminthol. 7: 41-132.

Williams H.H. 1964: Some new and little known cestodes from Australian elasmobranchs with a brief discussion on their possible use in problems in host taxonomy. Parasitology 54: 737748.

Accepted 4 October 2010 